\title{
Water exchange between the Sea of Azov and the Black Sea through the Kerch Strait
}

\author{
Ivan Zavialov $^{1}$, Alexander Osadchiev ${ }^{1}$, Roman Sedakov ${ }^{1,2}$, Bernard Barnier ${ }^{3,1}$, Jean-Marc Molines ${ }^{3}$, and \\ Vladimir Belokopytov ${ }^{4}$ \\ ${ }^{1}$ Shirshov Institute of Oceanology, Russian Academy of Sciences, Moscow, Russia \\ ${ }^{2}$ Department of Aerophysics and Space Research, Moscow Institute of Physics and Technology, Dolgoprudny, Russia \\ ${ }^{3}$ Institut des Géosciences de l'Environment, UGA/CNRS/IRD, Grenoble INP, Grenoble, France \\ ${ }^{4}$ Marine Hydrophysical Institute, Russian Academy of Science, Sevastopol
}

Correspondence: Alexander Osadchiev (osadchiev@ocean.ru)

Received: 28 January 2019 - Discussion started: 11 February 2019

Revised: 31 October 2019 - Accepted: 23 November 2019 - Published: 7 January 2020

\begin{abstract}
The Sea of Azov is a small, shallow, and freshened sea that receives a large freshwater discharge. Under certain external forcing conditions low-salinity waters from the Sea of Azov flow into the north-eastern part of the Black Sea through the narrow Kerch Strait and form a surface-advected buoyant plume. Water flow in the Kerch Strait also regularly occurs in the opposite direction, which results in the spreading of a bottom-advected plume of saline and dense waters from the Black Sea into the Sea of Azov. In this study we focus on the physical mechanisms that govern water exchange through the Kerch Strait and analyse the dependence of its direction and intensity on external forcing conditions. Analysis of satellite imagery, wind data, and numerical modelling shows that water exchange in the Kerch Strait is governed by a wind-induced barotropic pressure gradient. Water flow through the shallow and narrow Kerch Strait is a one-way process for the majority of the time. Outflow from the Sea of Azov to the Black Sea is induced by moderate and strong north-easterly winds, while flow into the Sea of Azov from the Black Sea occurs during wind relaxation periods. The direction and intensity of water exchange have wind-governed synoptic and seasonal variability, and they do not depend on the rate of river discharge to the Sea of Azov on an intraannual timescale. The analysed data reveal dependencies between wind forcing conditions and spatial characteristics of the buoyant plume formed by the outflow from the Sea of Azov.
\end{abstract}

\section{Introduction}

The Sea of Azov is an enclosed sea located in eastern Europe and is among the smallest and shallowest seas in the world (Fig. 1). The watershed area of the Sea of Azov $\left(586000 \mathrm{~km}^{2}\right)$ is 15 times greater than the sea area $\left(39000 \mathrm{~km}^{2}\right)$. Therefore, it receives an anomalously large river discharge, whose annual volume varies between 20 and $54 \mathrm{~km}^{3}$, which is only 1 order of magnitude smaller than the sea volume $\left(290 \mathrm{~km}^{3}\right)$ (Ross, 1977; Ilyin, 2009). In particular, $95 \%$ of the annual continental discharge is provided by the Don and Kuban rivers that flow into the north-eastern and south-eastern parts of the Sea of Azov, respectively (Ross, 1977; Ilyin, 2009). The southern part of the Sea of Azov is connected to the north-eastern part of the Black Sea through the long $(45 \mathrm{~km})$ and narrow $(4-15 \mathrm{~km})$ Kerch Strait. Hydrological characteristics and the general circulation of the Sea of Azov are governed by local winds, river runoff, and water exchange with the Black Sea. Low water salinity (1-12) (Ross, 1977; Goptarev et al., 1991; and Ilyin, 2009) caused by a large freshwater discharge and limited water exchange with the more saline Black Sea (17-18) (Ivanov and Belokopytov, 2011) through the narrow Kerch Strait is one of the main features of the Sea of Azov. Thus, the Sea of Azov is a small, shallow, and brackish body of water that can be regarded as the large estuary of the Don and Kuban rivers connected with the Black Sea through the Kerch Strait.

Limited water exchange through a narrow strait hinders mixing between connected bodies of water, which can re- 


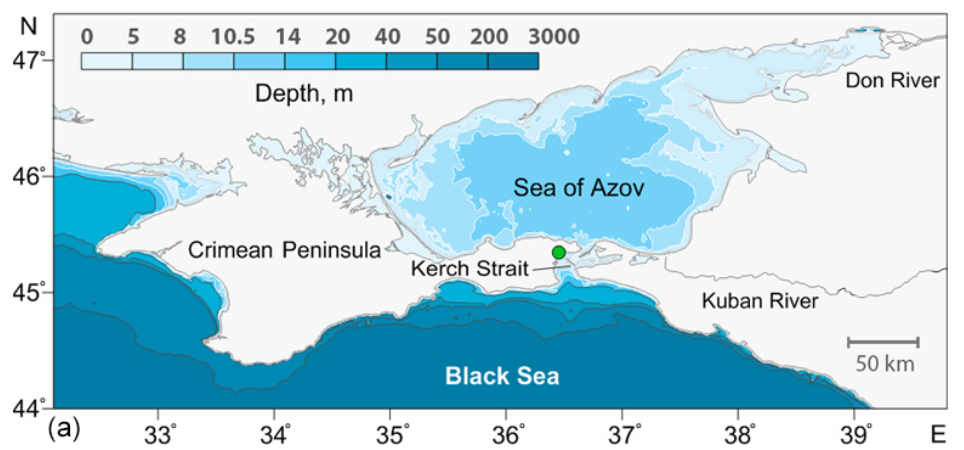

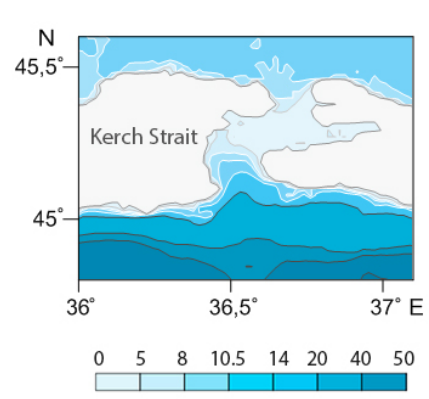

(b)

Figure 1. Bathymetry of the Sea of Azov and the north-eastern part of the (a) Black Sea and the (b) Kerch Strait. Locations of the estuaries of the Don and Kuban rivers and the Kerch meteorological station (green circle).

sult in substantial differences between their physical and chemical characteristics, particularly in concentrations of dissolved and suspended constituents. Thus, the transport of water masses through a strait and their subsequent spreading in adjacent sea areas can greatly influence many local processes including coastal circulation, primary productivity, water quality, anthropogenic pollution, and deposition of terrigenous material. The impact of water exchange on these processes depends on, first, the physical and chemical characteristics of the interacting water masses and, second, the variability in the water exchange direction, i.e. frequency, duration, and intensity of water exchange periods.

Many previous studies were focused on physical, biological, and geochemical processes related to water exchange between two large bodies of water through a narrow strait in different world regions; in particular this includes the Baltic and North seas through the Danish Straits (Matthäus and Lass, 1995; Sayin and Kraus, 1996; Jacobsen and Trebuchet, 2000; Sellschoppa et al., 2006; and She et al., 2007), the Black and Mediterranean seas through the Bosporus and Dardanelles straits (Yuce, 1996; Andersen et al., 1997; Gregg et al., 1999; Falina et al., 2017; Sozer and Ozsoy, 2017; and Stanev et al., 2017), the Mediterranean Sea and the Atlantic Ocean through the Strait of Gibraltar (Garret, 1996; Sannino et al., 2002; Beranger et al., 2005; and Soto-Navarro et al., 2015), the Bering and Chukchi seas through the Bering Strait (Woodgate et al., 2006, 2010, 2012; Danielson et al., 2014), and the Patos Lagoon and the Atlantic Ocean (Castelao and Moller, 2006; Marques et al., 2009). A number of papers addressed the structure of and variability in circulation in the Kerch Strait (Simonov and Altman, 1991; Lomakin et al., 2010, 2016, 2017; Sapozhnikov et al., 2011; Chepyzhenko et al., 2015; and Kubryakov et al., 2019) and the influence of water inflow from the Sea of Azov on the coastal ecosystem in the north-eastern part of the Black Sea (Lomakin et al., 2010; Kolyuchkina et al., 2012; Aleskerovà et al., 2017; Izhitsky and Zavialov, 2017; and Zavialov et al., 2018). However, many aspects of the physical background of water exchange through the Kerch Strait and its dependence on exter- nal forcing conditions remain unstudied. Also, little attention has been paid to spatial characteristics and temporal variability in sub-mesoscale and mesoscale structures formed in the Black Sea and the Sea of Azov as a result of water exchange between these seas.

In this study, we address the physical mechanisms that drive water exchange between the Sea of Azov and the Black Sea, using colour satellite imagery of the ocean, wind reanalysis data, river gauge measurements, and numerical modelling. First, we reveal the dependence of direction and intensity of water exchange through the Kerch Strait on external forcing conditions. Second, we analyse the dynamics of the surface-advected plume of brackish waters from the Sea of Azov spreading in the Black Sea (hereafter this plume is referred to as the AP), and the bottom-advected plume of saline waters from the Black Sea spreading in the Sea of Azov (hereafter this plume is referred to as the BP). Finally, we reveal the dependence of spatial characteristics of the AP on external forcing conditions.

The paper is organized as follows. Section 2 provides the detailed information about the study region. Satellite, wind, and river discharge data as well as the numerical model used for simulation of sea circulation in this study region are described in Sect. 3. Section 4 focuses on the dynamics of inflow and spreading of the AP in the Black Sea and the BP in the Sea of Azov, and it addresses the dependence of these processes on the external forcing conditions on a synoptic timescale. A discussion of the obtained results followed by the conclusions is given in Sect. 5.

\section{Study area}

The Sea of Azov is small and shallow; its average and maximal depths are 7 and $14.4 \mathrm{~m}$. The central part of the Sea of Azov is $10-13 \mathrm{~m}$ deep and accounts for less than $50 \%$ of the sea area (Fig. 1). The southern part of the Sea of Azov is connected with the north-eastern part of the Black Sea by the Kerch Strait. The narrowest passages of the Kerch Strait are located at its northern $(4-5 \mathrm{~km})$ and central $(3 \mathrm{~km})$ parts, 
while at its southern part the strait width increases (up to $15 \mathrm{~km})$. The central part of the Kerch Strait is very shallow (3-5 m) and steadily deepens to depths of 10 and $20 \mathrm{~m}$ at its northern and southern parts, respectively. Bathymetry of the north-eastern part of the Black Sea is characterized by the narrow shelf; the distance from the shore to the $100 \mathrm{~m}$ isobath varies between 15 and $30 \mathrm{~km}$ (Fig. 1).

A large freshwater discharge strongly influences the Sea of Azov. The Don River is the largest river flowing into the Sea of Azov, providing approximately $65 \%$ of the total freshwater runoff to the sea. The Kuban River provides another $30 \%$ of the total freshwater runoff. The volumes of annual discharge of the Don and Kuban rivers vary from 18 to $28 \mathrm{~km}^{3}$ and from 6 to $13 \mathrm{~km}^{3}$, respectively; this is caused by strong climatic and anthropogenic influences (Goptarev et al., 1991; Ilyin et al., 2009). Flow regimes of the Don and Kuban rivers have long spring-summer freshets during March-June and April-July, respectively. However, discharges during these periods are only 2 times larger than during the rest of the year (Goptarev et al., 1991; Ilyin et al., 2009). The difference between evaporation and precipitation over the Sea of Azov $\left(17 \mathrm{~km}^{3}\right)$ is less than half as much as the mean annual river runoff $\left(35 \mathrm{~km}^{3}\right)$ and shows very low interannual variability (Ilyin et al., 2009).

Surface temperature in the Sea of Azov is prone to large seasonal variability, from $0{ }^{\circ} \mathrm{C}$ in winter to $25^{\circ} \mathrm{C}$ in summer (Goptarev et al., 1991; Ilyin et al., 2009). Sea ice covers the northern part of the Sea of Azov every year from DecemberJanuary to March-April, while its central and southern parts are only frozen during extremely cold winters, which has only occurred twice during the last 40 years (Ilyin et al., 2009). Surface salinity in the Sea of Azov varies from 9 to 13 except for the most freshened north-eastern part, namely, Taganrog Bay, which receives discharge from the Don River. Wind-induced mixing penetrates to the sea bottom, which results in low gradients in the vertical thermohaline structure of the Sea of Azov (Goptarev et al., 1991; Ilyin et al., 2009). Temperature in the surface layer of the north-eastern part of the Black Sea also varies largely, from $7^{\circ} \mathrm{C}$ in winter to $23^{\circ} \mathrm{C}$ in summer; however, its salinity is stable (17-19) during the whole year (Ivanov and Belokopytov, 2013). A large freshwater discharge and intense wind-induced vertical mixing result in high concentrations of terrigenous sediments, nutrients, and chlorophyll $a$ in the Sea of Azov, which are 1 order of magnitude greater than in the north-eastern part of the Black Sea (Ilyin et al., 2009).

Circulation in the Sea of Azov is mainly wind-driven, while baroclinic forcing is weak (Cherkesov and Shul'ga, 2018). As a result, the sea current field and the level of the Sea of Azov are prone to large synoptic variability caused by intense wind surges in which amplitudes regularly exceed $2 \mathrm{~m}$ (Ivanov, 2011; Fomin, 2015, 2017). Circulation in the surface layer in the north-eastern part of the Black Sea is dominated by, first, the westward current along the continental slope $\left(0.2-0.5 \mathrm{~m} \mathrm{~s}^{-1}\right)$, which is a part of the Black Sea
Rim Current, and, second, the anticyclonic eddy, which is regularly formed between this current and the coast near the Kerch Strait (0.05-0.4 m s ${ }^{-1}$ ) (Oguz et al., 1993; Ginzburg et al., 2002; Zatsepin et al., 2003; and Korotaev et al., 2003). Tidal amplitudes at the north-eastern part of the Black Sea and in the Sea of Azov are 2-4 cm; thus, tidal circulation is very low in the study area (Medvedev et al., 2016; Medvedev, 2018).

Water transport through the Kerch Strait is an important part of the water budget of the Sea of Azov; however, its characteristics are prone to large uncertainty. Volumes of annual water inflow from the Sea of Azov to the Black Sea, and in the opposite direction, are estimated as 35-64 and 26$44 \mathrm{~km}^{3}$, respectively. Current velocities in the Kerch Strait generally exceed $10 \mathrm{~cm} \mathrm{~s}^{-1}$; mean current velocities in its narrowest part are $20-30 \mathrm{~cm} \mathrm{~s}^{-1}$. Barotropic tidal current in the Kerch Strait is less than $5 \mathrm{~cm} \mathrm{~s}^{-1}$ except in the narrowest part of the strait where they are equal to $6-10 \mathrm{~cm} \mathrm{~s}^{-1}$ during the peak flow (Ferrain et al., 2018). However, the maximal velocity of the tidal current averaged over $2 \mathrm{~d}$ in the Kerch Strait is less than $5 \mathrm{~cm} \mathrm{~s}^{-1}$ and its flow direction reverses during the tidal cycle. Thus, tidal currents do not form persistent residual flow and their roles in water exchange between the Black and Azov seas can be regarded as negligible.

A large salinity difference between the Azov and Black seas results in substantially different spreading and mixing dynamics of waters that flow from the Sea of Azov into the Black Sea, compared with waters that flow from the Black Sea into the Sea of Azov. Inflow of brackish waters from the Sea of Azov into the Black Sea forms a surface-advected $\mathrm{AP}$, which spreads over wide areas (up to $2000 \mathrm{~km}^{3}$ ) in the north-eastern part of the Black Sea (Aleskerovà et al., 2017; Kubryakov et al., 2019). Due to elevated concentrations of terrigenous sediments, nutrients, and anthropogenic pollutants in the waters of the Sea of Azov, the AP strongly influences physical, biological, and geochemical processes in the areas adjacent to the Kerch Strait in the north-eastern part of the Black Sea (Lomakin et al., 2010; Kolyuchkina et al., 2012; Aleskerovà et al., 2017; Izhitsky and Zavialov, 2017; and Zavialov et al., 2018). The AP is regularly entrained by mesoscale eddies formed in the Black Sea near the Kerch Strait that can significantly intensify cross-shelf transport of low-salinity water in the Black Sea (Kubryakov et al., 2019).

Processes of inflow, spreading, and mixing of Black Sea waters in the Sea of Azov have received much less attention. Saline waters from the Black Sea form a bottom-advected BP, which can affect large areas in the Sea of Azov. However, its characteristics, spatial structure, and temporal variability remain mainly unstudied. 


\section{Data and methods}

\subsection{Data used}

Satellite data used in this study include satellite imagery from the Envisat MERIS with a spatial resolution of $300 \mathrm{~m}$, provided by the European Space Agency (ESA), and from Terra MODIS and Aqua MODIS with a spatial resolution of $250 \mathrm{~m}$, provided by the National Aeronautics and Space Administration (NASA). MERIS L1 satellite products were downloaded from the ESA web repository (https://earth.esa.int/ web/guest/-/meris-full-resolution-full-swath-4215; last access: 20 November 2019) and used for retrieving maps of sea surface distributions of total suspended matter (TSM) and chlorophyll $(\mathrm{Chl} a$ ) using the MERIS Case 2 Water Algorithm (Doerffer and Schiller, 2007). MODIS L1 satellite products were downloaded from the NASA web repository (https://ladsweb.modaps.eosdis.nasa.gov/; last access: 20 November 2019) and used for retrieving maps of sea surface distributions of TSM and Chl $a$ using the MSL12 processing module. We analysed 152 MERIS and 155 MODIS satellite images of the study region taken in 2002-2012 and 2012-2019, respectively.

Don and Kuban discharge and local wind forcing data were used to study the influence of external forcing conditions on water exchange through the Kerch Strait and spreading of the AP in the north-eastern part of the Black Sea. The Don and Kuban daily discharge data were obtained from the Razdorskaya and Temryuk gauge stations, respectively, while local wind measurements were performed at the Kerch meteorological station (Fig. 1). Atmospheric influence was also examined using wind data obtained from a $6 \mathrm{~h}$ NCEP/NCAR reanalysis with a $2.5^{\circ}$ resolution, which was in good accordance with in situ data for the study region (Garmashov et al., 2016). We used zonal and meridional wind components from the only reanalysis grid point located in the study area $\left(44.7611^{\circ} \mathrm{N}, 35.625^{\circ} \mathrm{E}\right)$ which were validated against the in situ wind measurements.

\subsection{Identification of the AP and the BP by satellite imagery}

As it was discussed in Sect. 3.1, waters of the Azov and Black seas have very different physical and chemical properties. As a result, various ocean surface characteristics measured by satellite instruments can be used to study spreading of the surface-advected AP in the north-eastern part of the Black Sea. Previous related studies used sea surface temperature (SST), concentrations of Chl $a$, and TSM retrieved from optical satellite data (Ivanov and Belokopytov, 2011; Aleskerovà et al., 2017; and Kubryakov et al., 2019). However, all of these characteristics cannot be used for a straightforward identification of the inflow of brackish waters from the Sea of Azov to the Black Sea, hereafter referred to as AI, and identification of boundaries of the AP due to the reasons that follow.

First, the difference in SST between the southern part of the Sea of Azov and the north-eastern part of the Black Sea varies from $-4{ }^{\circ} \mathrm{C}$ in winter to $+4{ }^{\circ} \mathrm{C}$ in summer (Aleskerovà et al., 2017). On the other hand, the diurnal variability in SST in the coastal areas of the Sea of Azov and the Black Sea is also equal to several degrees (Ivanov and Belokopytov, 2011; Chepyzhenko et al., 2015). This fact can prevent the formation of distinctive frontal zones between the AP and the adjacent sea, especially if the AP is formed by inflow from the Sea of Azov over several days, i.e. several diurnal temperature cycles of SST. Mean seasonal and diurnal variability in TSM is much lower than the difference between the mean values of TSM in the Azov and Black seas during the year (Lomakin et al., 2017). The settling time of fine suspended sediments within the AP is much lower than the residence time of the AP in the Black Sea; i.e. the AP mixes with ambient saline water and dissipates more quickly than fine suspended sediments settle from the surface layer to the subjacent sea. Thus, TSM provides a clear optical signal of a turbid $\mathrm{AP}$ in the Black Sea and forms stable gradients at the borders of the AP, which are distinctly visible in optical satellite imagery. However, wind-induced resuspension of sea bottom sediments, which regularly occurs along the north-eastern coast of the Black Sea, causes an increase in TSM, which can exceed mean TSM values of the AP (Fig. 2a). Chl $a$, in contrast to TSM, is characterized by, first, a larger seasonal variability in the differences between it in the Azov and Black seas during the year and, second, a larger synoptic variability within the AP, caused by complex biological processes. However, Chl $a$ has lower short-term variability, particularly in response to wind forcing.

As it was shown above, surface distributions of SST, TSM, and Chl $a$ in the study region are prone to substantial variability defined by various processes apart from mixing between waters from the Black and Azov seas. However, these processes and their temporal scales are different for SST (diurnal cycle of solar radiation), TSM (episodic wind-induced bottom resuspension events), and $\mathrm{Chl} a$ (synoptic and seasonal biological cycles). Thus, joint analysis of SST, TSM, and Chl $a$ distributions can be used to accurately detect spreading of the AP in the Black Sea. We applied the following scheme for the identification of $\mathrm{AI}$ events and the detection of the borders of the AP based on satellite data. Inflow events were identified by an elevated concentration of Chl $a$ in the Kerch Strait and the adjacent coastal area of the Black Sea because Chl $a$ has the lowest short-term variability among the considered sea surface characteristics. If an inflow event was detected, we analysed areas of elevated TSM, Chl $a$, and elevated (in summer) or reduced (in winter) SST associated with the formation of the AP in the north-eastern part of the Black Sea. If general forms and spatial scales of these areas were similar, we defined the borders of the AP based on the gradient of TSM, which is the most stable passive tracer of the AP 
(a)
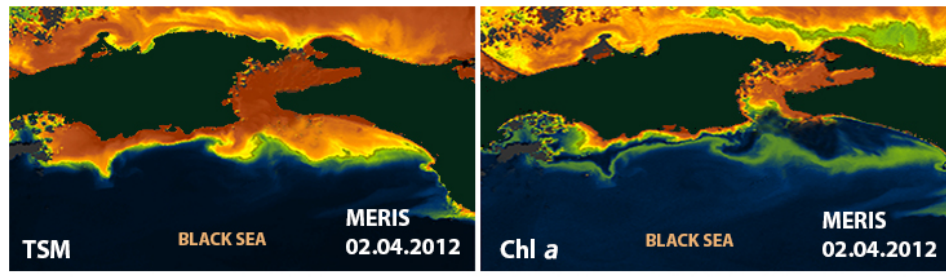

(b)
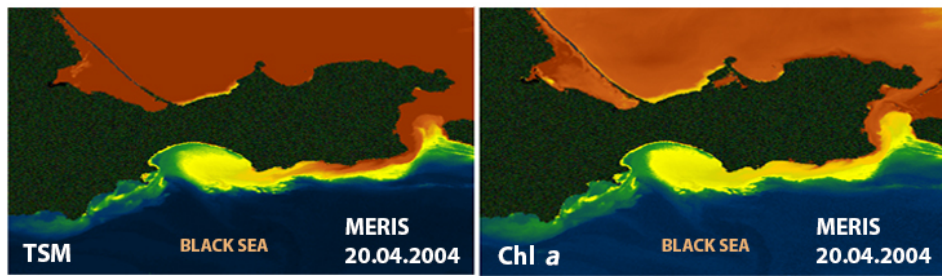

$\operatorname{TSM}\left(\mathrm{g} \mathrm{m}^{-3}\right)$, Chl a $\left(\mathrm{mg} \mathrm{m}^{-3}\right)$

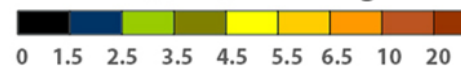

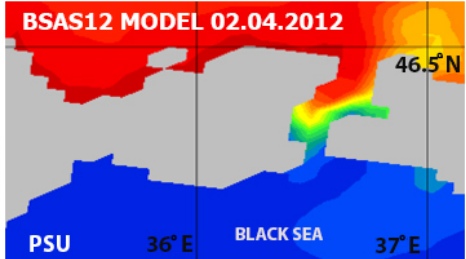
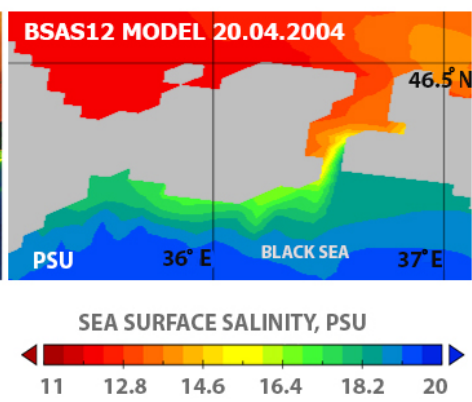

Figure 2. Sea surface distributions of TSM (left) and Chl $a$ (middle) retrieved from MERIS satellite data and sea surface salinity distribution obtained from numerical modelling (right), indicating (a) wind-induced resuspension of sea bottom sediments at the study area on 2 April 2012 and (b) spreading of the AP on 20 April 2004.

in the absence of episodic wind-induced bottom resuspension events (Fig. 2b). If areas of TSM, Chl $a$, and SST anomalies were not consistent with each other, we assumed that areas of elevated TSM and reduced SST (in winter) were modified by wind-induced resuspension and mixing of the AP with the subjacent sea. In this case we defined borders of the AP based on the gradient of $\mathrm{Chl} a$, which is the most stable tracer of the $\mathrm{AP}$ under intense wind forcing conditions during the year.

Inflow of saline waters from the Black Sea to the Sea of Azov, hereafter referred to as BI, causes the formation of a bottom-advected BP that cannot be directly identified in satellite imagery. However, wind-induced mixing, which regularly penetrates to sea bottom at the shallow Sea of Azov, can cause BP water to mix with overlying water in the Sea of Azov. It results in reduced values of TSM and Chl $a$ in the surface layer above the spreading area of the BP, compared to the adjacent areas of the Sea of Azov. Thus, the presence of the BP in the bottom layer can be identified in satellite imagery as areas of reduced TSM and Chl $a$ in the Sea of Azov adjacent to the BP in the Kerch Strait. The scheme of identification of BI events and detection of BP borders in satellite imagery is relatively straightforward when compared to the identification of AI events. However, we assume that the BP is not manifested by anomalous TSM and Chl $a$ in the surface layer during low wind forcing conditions because during strong wind forcing conditions resuspension of bottom sediments can induce elevated concentrations of TSM in the surface layer that also hinder identification of the BP. As a result, many of BI events are not detected in optical satellite imagery.

\subsection{Numerical model}

In this study we performed numerical simulations using the BSAS12 numerical model to simulate circulation in the Black and Azov seas and study water exchange through the Kerch Strait. BSAS12 is an original regional configuration of the ocean and sea ice general circulation model NEMO (version 3.6) that covers the Black and Azov seas (Madec and the NEMA team, 2016). Horizontal grid resolution of the model is $1 / 12^{\circ}$, which is approximately $6.75 \mathrm{~km}$ in the study region. The vertical coordinate is represented by 59 vertical $z$ levels with the finest resolution $(1 \mathrm{~m})$ at the upper ocean. A partial-step representation of bottom topography that adjusts vertical size of the model bottom level to the real ocean depth is used (Barnier et al., 2006). The model domain has an open ocean boundary at the Bosporus Strait that connects the Black Sea with the Mediterranean Sea. The ocean is driven by the ERA-Interim (https://www.ecmwf. int/en/forecasts/datasets/reanalysis-datasets/era-interim; last access: 20 November 2019)atmospheric forcing, which includes $3 \mathrm{~h}$ fields of near-surface wind velocity, temperature, and humidity and daily fields for incoming long- and shortwave radiation and total precipitation. Surface fluxes and wind stress are calculated using the CORE bulk formulae (Large and Yeager, 2004) using sea surface temperature provided by the model. The initial temperature and salinity fields of the Azov and Black seas are obtained from the climatological data given in Goptarev et al. (1991) and Belokopytov (2018). BSAS12 is forced by monthly climatological river runoff to the Black and Azov seas that was set according to the data provided in Jaoshvili (2002) and Dai and Trenberth (2002); it also uses gauge data from the Don and Kuban 


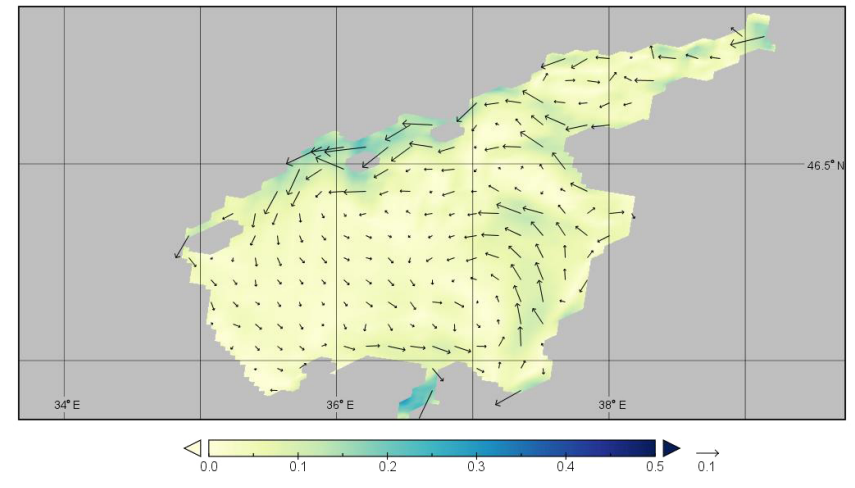

Figure 3. Daily snapshot of the surface velocity field on 15 January 1994. It illustrates the cyclonic Rim Current, the quasipermanent anticyclonic currents (Batumi, Sochi, and Sevastopol), and the westward outflow from the Kerch Strait spreading along the Crimean Peninsula.

rivers, as described in Sect. 3.1. The boundary conditions at the Bosporus Strait are prescribed according to the data provided by Gregg et al. (1999), Gregg and Ozsoy (2002), Altiok et al. (2012), and Sozer and Ozsoy (2017). The model time step is set to $720 \mathrm{~s}$. The BSAS12 model simulates circulation of the Black and Azov seas for the period from 1 January 1992 to 31 December 2017. In this study we focus on modelling circulation in areas of the Black and Azov seas adjacent to the Kerch Strait with an emphasis on water exchange through the strait. The main large-scale and mesoscale circulation features of the Black Sea circulation were adequately reproduced by numerical modelling (Fig. 3), including the Black Sea Rim Current, the quasi-stationary cyclonic gyres at the central divergence zone, and the multiple quasi-stationary anticyclonic gyres between the Rim Current and the shoreline near Sevastopol, Batumi, etc. (Oguz et al., 1992, 1993, 1995; Staneva et al., 1995, 2001). The model also accurately reproduced seasonal variations in sea surface circulation, particularly the winter-spring intensification of the Rim Current, the meandering of the main flow of the Rim Current caused by baroclinic instability, and the formation of multiple nearshore anticyclonic eddies during summer at the eastern part of the Black Sea (Oguz et al., 1992, 1993; Titov, 2002; Zatsepin et al., 2003; and Enriquez et al., 2005). The mean annual values of the water transport through the Kerch Strait during the modelling period (Fig. 4) are in good agreement with the reference values of $20 \mathrm{~km}^{3}$ (Stanev, 1990). A short assessment of the surface circulation produced by the model is presented in the Supplement.

\section{Results}

\subsection{Water exchange through the Kerch Strait}

We used the BSAS12 model to study physical mechanisms that govern water exchange through the Kerch Strait. Based
Table 1. The flow direction statistics in the Kerch Strait for the period from 1992 to 2010, obtained by the BSAS12 numerical model simulation.

\begin{tabular}{rrrr}
\hline Year & $\begin{array}{r}\text { Only into } \\
\text { Black Sea, } \\
\text { days }\end{array}$ & $\begin{array}{r}\text { Only into } \\
\text { Sea of Azov, } \\
\text { days }\end{array}$ & $\begin{array}{r}\text { In both } \\
\text { directions, } \\
\text { days }\end{array}$ \\
\hline 1992 & 178 & 145 & 43 \\
1993 & 177 & 152 & 36 \\
1994 & 169 & 150 & 46 \\
1995 & 180 & 150 & 35 \\
1996 & 171 & 153 & 42 \\
1997 & 181 & 150 & 34 \\
1998 & 173 & 146 & 46 \\
1999 & 171 & 158 & 36 \\
2000 & 168 & 156 & 42 \\
2001 & 167 & 150 & 48 \\
2002 & 170 & 150 & 45 \\
2003 & 181 & 139 & 45 \\
2004 & 174 & 152 & 40 \\
2005 & 172 & 145 & 48 \\
2006 & 167 & 146 & 52 \\
2007 & 161 & 154 & 50 \\
2008 & 176 & 149 & 41 \\
2009 & 166 & 145 & 54 \\
2010 & 163 & 157 & 45 \\
\hline & & &
\end{tabular}

on the simulation outputs, we reconstructed daily averaged baroclinic and barotropic components of the pressure gradient force in the Kerch Strait for the years 1992-2017. A correlation analysis shows that the total pressure gradient along the strait is mostly governed by the barotropic component $(R=0.7)$, while the role of the baroclinic component is smaller $(R=0.3)$. This feature is caused by a relatively large average difference in water level $(<0.1 \mathrm{~m}$ during the majority of a year) in the southern and northern ends of the strait. Local wind forcing induces large synoptic variability in the magnitude and direction of the barotropic pressure gradient. The stable density jump that exists along the strait does not exceed $6 \mathrm{~kg} \mathrm{~m}^{-3}$; therefore, the baroclinic pressure gradient is 1 order of magnitude smaller than the barotropic pressure gradient and does not induce the steady exchange circulation typical for positive estuaries. As a result, circulation through the Kerch Strait is not steady and unidirectional but has large synoptic variability in intensity and direction, governed by episodic wind forcing events. Annual variability in the total pressure gradient in the strait does not show any seasonality. Thus, water exchange through the Kerch Strait has windgoverned synoptic variability and does not have a seasonal dependence on the rate of river discharge to the Sea of Azov.

The role of the barotropic component in the total pressure gradient is largest in the most shallow $(3-4 \mathrm{~m})$ and narrow $(3 \mathrm{~km})$ parts of the Kerch Strait. Numerical simulations revealed that even moderate wind forcing in the study region induces a one-way water transport (i.e. only inflow or only 


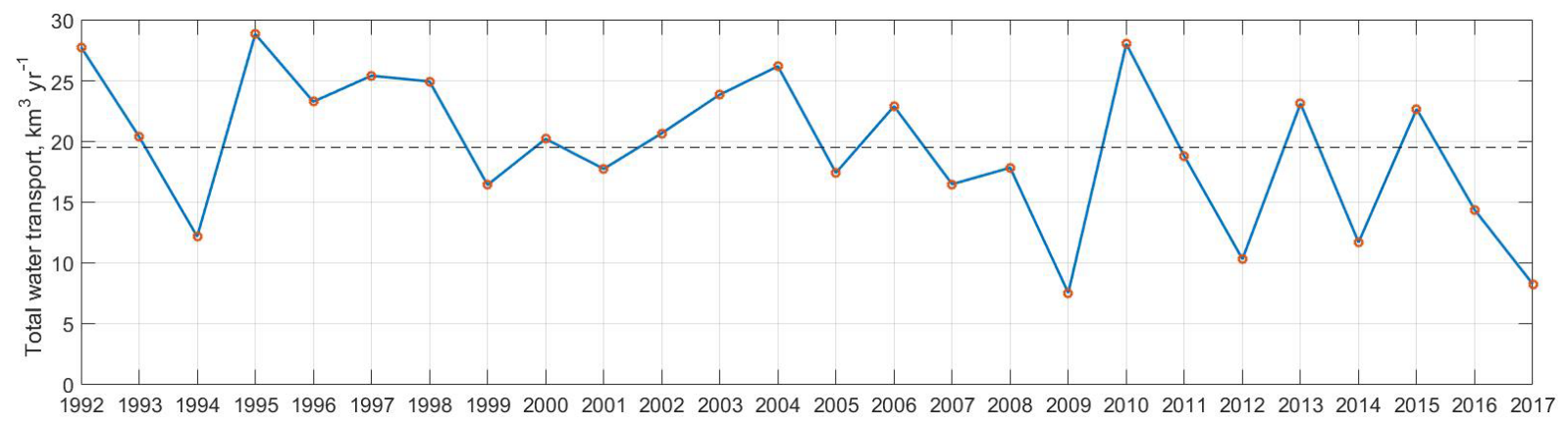

Figure 4. Yearly mean values of total water transport through the Kerch Strait in $\mathrm{km}^{3} \mathrm{yr}^{-1}$. Dashed line: average yearly transport over the entire period of the experiment.

outflow) in this part of the strait, which defines water exchange between the Azov and Black seas. Water flow occurs simultaneously in both directions in the shallow part of the strait (i.e. a two-way water transport is formed) only during light winds. Numerical simulations show that a two-way water exchange occurred in the Kerch Strait only during weak wind forcing conditions, which had a total annual duration of $34-54 \mathrm{~d}$ in $1992-2010$; that is only $9 \%-15 \%$ of a year (Table 1). Thus, a one-way water exchange between the Azov and Black seas was observed during the majority of the year, which is not typical for a positive estuary. This result is also supported by previous studies based on in situ observations (Ivanov et al., 2011) and numerical modelling (Stanev et al., 2017) of water exchange in the Kerch Strait.

\subsection{Spreading of the AP in the Black Sea}

River discharge to the Sea of Azov and wind forcing in the area of the Kerch Strait are the main factors believed to govern AI events (Goptarev et al., 1991; Simonov and Altman, 1991; and Ivanov and Belokopytov, 2013). We analysed 68 AI events identified in MERIS and MODIS optical satellite imagery for the years 2002-2019 and verified them using the BSAS12 simulations. Based on wind reanalysis data and gauge data of the Don and Kuban rivers, we studied the dependence of the formation of AI events on wind forcing conditions and river discharge on synoptic and seasonal timescales.

First, we analysed the relation between the concentration of Chl $a$ in the Kerch Strait and the adjacent area of the Black Sea retrieved from optical satellite imagery, on the one hand, and the direction of wind forcing averaged over the $24 \mathrm{~h}$ preceding satellite observations, on the other hand (Fig. 5). Elevated concentrations of $\mathrm{Chl} a$, which is regarded as the main indicator of an AI event, were only observed if the azimuthal angle of the wind direction was between 30 and $80^{\circ}$ and the wind velocity exceeded $5 \mathrm{~m} \mathrm{~s}^{-1}$. Thus, the formation of an AI event is only induced by moderate and strong north-easterly winds. Second, we addressed the relation between the concentration of Chl $a$ and the discharge rates of the Don and

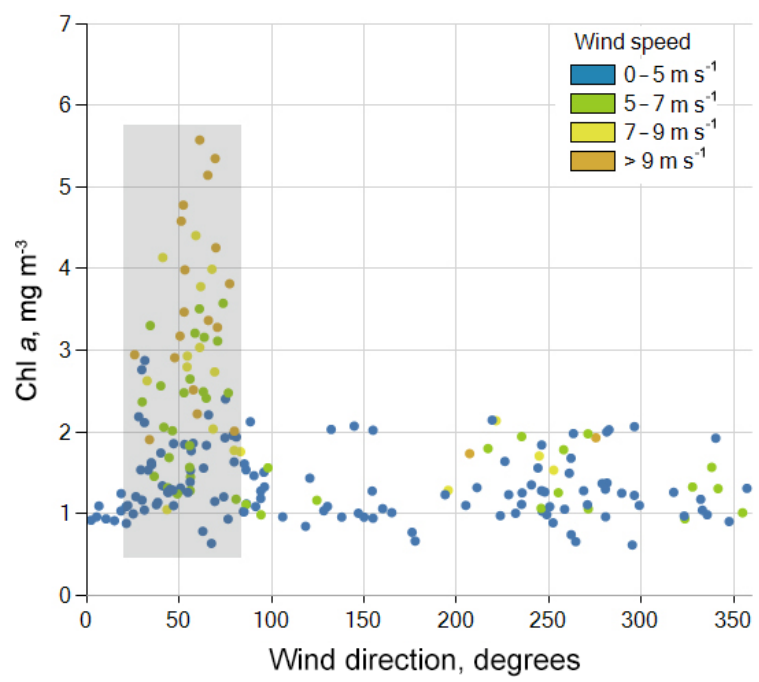

Figure 5. Dependence between the concentration of Chl $a$ in the Kerch Strait and the adjacent area of the Black Sea retrieved from optical satellite imagery, on the one hand, and the direction of wind forcing averaged over $24 \mathrm{~h}$ preceding satellite observations, on the other hand.

Kuban rivers (Fig. 6). We obtained results showing that AI events are formed under a whole variety of discharge conditions and do not depend on the discharge rate on a synoptic timescale. Synoptic variability in river discharge strongly influences water exchange between a river estuary and the open sea if the volume of an estuary is relatively small compared to the river discharge rate (Miranda, 2017; Officer, 1976; Sheldon and Alber, 2002; and Wang et al., 2004). However, the volume of the Sea of Azov, regarded as the estuary of the Don and Kuban rivers, is 1 order of magnitude greater than the annual freshwater runoff. As a result, any signal of synoptic variability in river discharge dissipates in the Sea of Azov and does not influence the formation of AI events. Thus, we obtain the result that AI events are induced by wind forcing and do not depend on river discharge conditions on a synoptic timescale. 


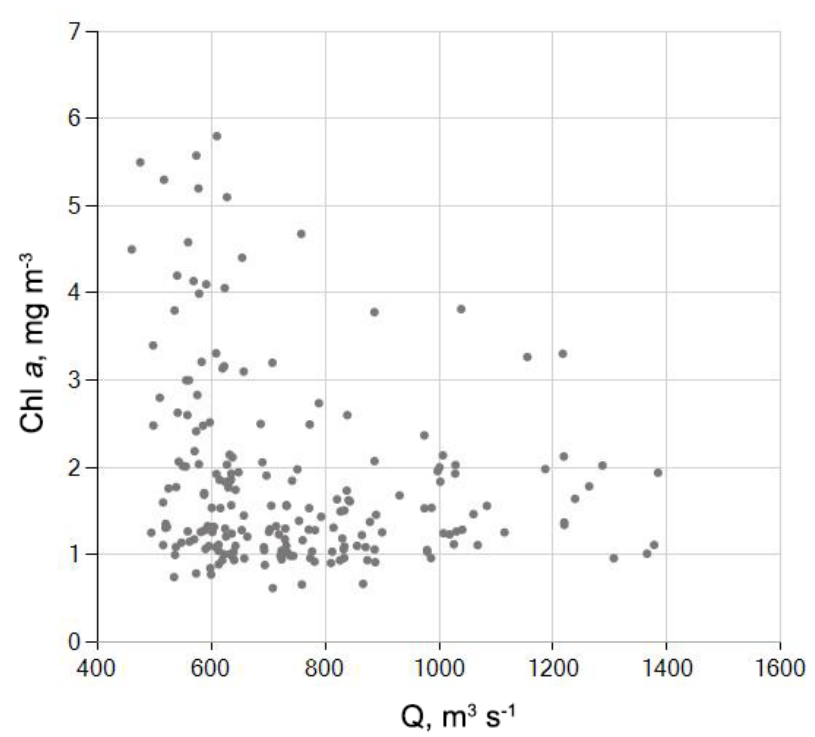

Figure 6. Dependence between the concentration of Chl $a$ in the Kerch Strait and the adjacent area of the Black Sea retrieved from optical satellite imagery, on the one hand, and total discharge of the Don and Kuban rivers, on the other hand.

Spreading of a buoyant plume in a non-tidal sea is mainly governed by the discharge rate and wind forcing (Fong et al., 1997; Hallock and Marmorino, 2002; Horner-Devine et al., 2015; and Osadchiev and Sedakov, 2019) and is characterized by strong variability in size, shape, and spreading patterns under different configurations of external forcing conditions (Kourafalou et al., 1996; Xia et al., 2007; Zavialov et al., 2014; Osadchiev et al., 2016, 2017; and Osadchiev and Korshenko, 2017). However, analysis of satellite imagery and numerical modelling revealed the stability of the spreading pattern of the AP. All satellite images where an AI event was detected showed that the AP propagated westward along the south-eastern shore of the Crimean Peninsula (Figs. 2b, 7). This result is supported by the BSAS12 numerical simulations that showed good agreement between the modelled distribution of the low-salinity AP and the location of the AP detected in optical satellite imagery. This freshened alongshore current formed by the AP dissipated at a distance of 50-200 km from its source at the Kerch Strait. The AP did not spread eastward along the coast of the Taman Peninsula or southward to the open sea. Elevated values of TSM to the east of the Kerch Strait along the Taman Peninsula, which are regularly observed in satellite imagery, are accompanied by neither elevated values of Chl $a$ nor low surface salinity (Fig. 2a). This fact indicates that these turbidity features are induced by bottom resuspension and do not correspond to the eastward spreading of the AP along the coast of the Taman Peninsula.

Stability of the spreading pattern of the AP can be explained in the following way. As it was shown above, AI only occurs with a north-easterly wind and causes the for- mation of the AP. Thus, initial spreading of the AP from its source at the Kerch Strait is forced by a north-easterly wind. As a result, the AP forms a quasi-geostrophic coastal current in response to downwelling-favourable wind forcing, which was addressed in many previous studies (Garvine, 1987; Yankovsky and Chapman, 1997; and Fong and Geyer, 2002). Spreading of the AP in different directions, e.g. southward or eastward, requires a change in direction of the wind forcing. However, a change in wind direction results in the cessation of brackish water inflow to the Black Sea, and it causes a dissipation of the freshened alongshore current.

Satellite imagery and numerical simulations show that the AP occupies a wide area along the south-eastern shore of the Crimean Peninsula in the case of a stable inflow of brackish waters from the Sea of Azov to the Black Sea over a period of 3-5 d (Fig. 7). The alongshore extent and area of the AP can increase by 1 order of magnitude and exceed $150 \mathrm{~km}$ and $2000 \mathrm{~km}^{2}$, respectively, during an individual AI event. After secession of the inflow from the Sea of Azov to the Black Sea, the AP dissipates over several days. As it was shown above, the intensity of AI, i.e. the freshwater discharge rate, depends on local wind, which is, therefore, the only critical external force that governs synoptic variability in the spatial scale of the AP. Thus, we can reconstruct the dependence of spatial characteristics of the AP identified in satellite imagery using the speed and duration of north-easterly wind forcing. For this purpose, we used the wind forcing index $W_{t}=\tau_{t} \cdot t$, where $\tau_{t}$ is the average wind stress during the time period $t$ when the wind direction was between 30 and $80^{\circ}$. The alongshore extent and area of the AP were identified in 68 satellite images obtained during or shortly after the north-easterly wind forcing conditions. For every registered AI event we calculated values of the alongshore extent $(L)$ and area $(S)$ of the AP and compared them with values of the wind forcing index $W_{t}$ for the related periods of predominant north-easterly wind forcing preceding satellite observations. For all of these cases $W_{t}$ exceeded $332.8 \mathrm{~s} \mathrm{~N} \mathrm{~m}^{-2}$; therefore, we presume this value is the threshold for the formation of an AI event. The alongshore extent and area of the AP increase with an increase in the wind forcing index; however, this increase is not steady. In particular, the alongshore extent and area of the AP are almost stable if the wind forcing index exceeds $7 \times 10^{4} \mathrm{~s} \mathrm{~N} \mathrm{~m}^{-2}$. Thus, the observed forms of dependence between these two quantities have a good approximation by logarithmic functions. Figure 8 illustrates the obtained relations between $L$ and $S$, on the one hand, and $W_{t}$, on the other hand, which are as follows: $L=-186.9+74.1 \times \lg \left(W_{t}\right)(\mathrm{RMSE}$ is about $15 \mathrm{~km})$; $S=-2537.7+838.6 \times \lg \left(W_{t}\right)\left(\mathrm{RMSE}\right.$ is about $\left.163 \mathrm{~km}^{2}\right)$.

In this study we did not consider the impact of ambient sea currents of the Black Sea on spreading of the AP along the Crimean Peninsula. This impact is not negligible; in particular, intensification of the Rim Current enhances alongshore spreading of the AP, while the mesoscale anticyclonic eddy formed between the Rim Current and the Kerch Peninsula 
(a)

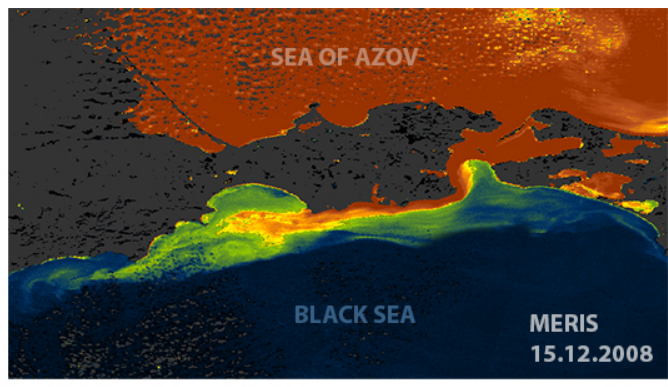

(b)
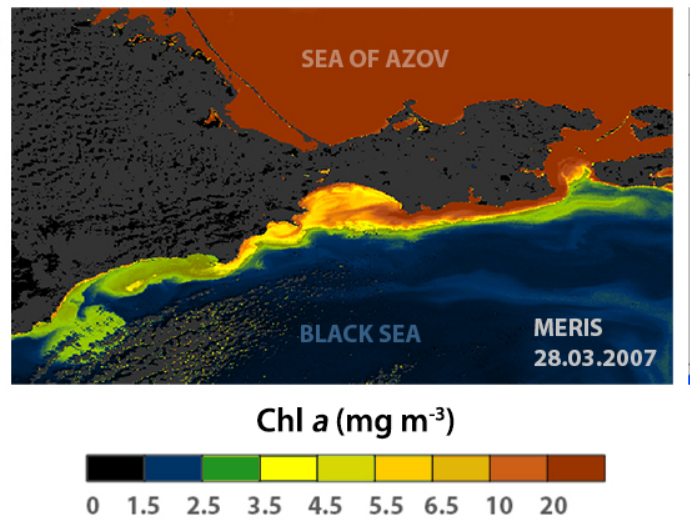
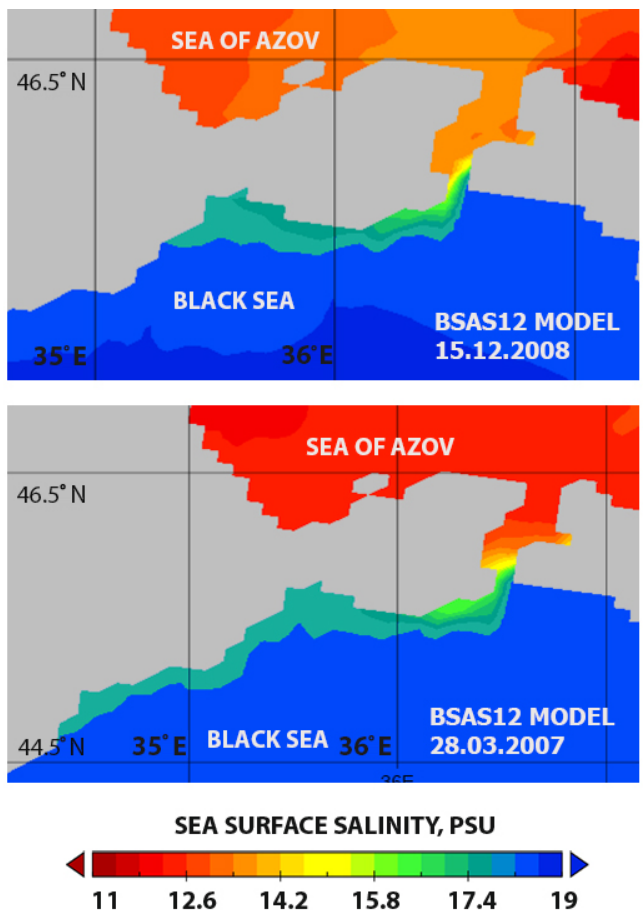

Figure 7. Sea surface distribution of Chl $a$ retrieved from MERIS satellite data (left) and sea surface salinity distribution obtained from numerical modelling (right) on (a) 12 December 2008 and (b) 28 March 2007.

induces cross-shore spreading of the AP (Kubryakov et al., 2019). However, the obtained relations and numerical modelling results show that spreading of the AP is mainly governed by wind forcing, while coastal circulation plays a secondary role, which is typical for buoyant surface-advected water masses (Washburn et al., 2003; Ostrander et al., 2008; Osadchiev and Zavialov, 2013; and Osadchiev, 2015).

Finally, we analysed the dependence of the seasonal variability in the area of the AP, which is indicative of the intensity of AI, on wind forcing and river discharge conditions. For this purpose we calculated monthly averages of the area of the AP detected in optical satellite imagery and compared them with monthly averages of the wind forcing index and total discharge rate of the Don and Kuban rivers (Fig. 9). Monthly variability in the average area of the AP shows a direct relation with monthly variability in the wind forcing index. The obtained graph reveals that both characteristics have similar monthly variations with two distinct peaks in September and December-March, while the lowest values are registered in May-June. However, the opposite situation is observed for the dependence between monthly averages of the area of the AP and river discharge rate. Several studies showed that variability in the Don and Kuban discharges induces variability in the level of the Sea of Azov, thus presumably influencing the formation of AI events on a seasonal timescale (Goptarev et al., 1991; Filippov, 2015). Nevertheless, seasonal variability in river discharge characterized by a distinct spring freshet and autumn-winter draught was shown to have no relation with the intensity of AI events. Thus, we obtain the result that river discharge does not significantly affect the seasonal variability of AI.

\subsection{Spreading of the BP in the Sea of Azov}

Inflow of saline waters from the Black Sea to the Sea of Azov causes the formation of a dense BP that spreads in the bottom layer and cannot be directly identified in satellite imagery. As it was described in Sect. 2.2, the BP can be identified in satellite imagery as an area of reduced TSM and Chl $a$ in the Sea of Azov adjacent to the Kerch Strait (Fig. 10). We analysed MERIS and MODIS optical satellite imagery acquired in 2002-2019 and only identified eight BI events that were confirmed by salinity distributions obtained from the BSAS12 numerical simulations. Thus, we assume that the BP is not manifested by anomalies of TSM and Chl $a$ in the surface layer during low wind forcing conditions, and many BI events are not detected in optical satellite imagery.

All identified BI events were preceded by strong northeasterly winds, which caused an intense outflow from the Sea of Azov to the Black Sea. Numerical simulations showed that the formation of BI events was caused by a reverse of the barotropic pressure gradient along the Kerch Strait as a result of a relaxation of strong north-easterly wind forcing. Figure 10 illustrates typical cases of the formation of BI events in response to local wind forcing. Strong northeasterly wind (up to $15 \mathrm{~m} \mathrm{~s}^{-1}$ ) observed for the time period 

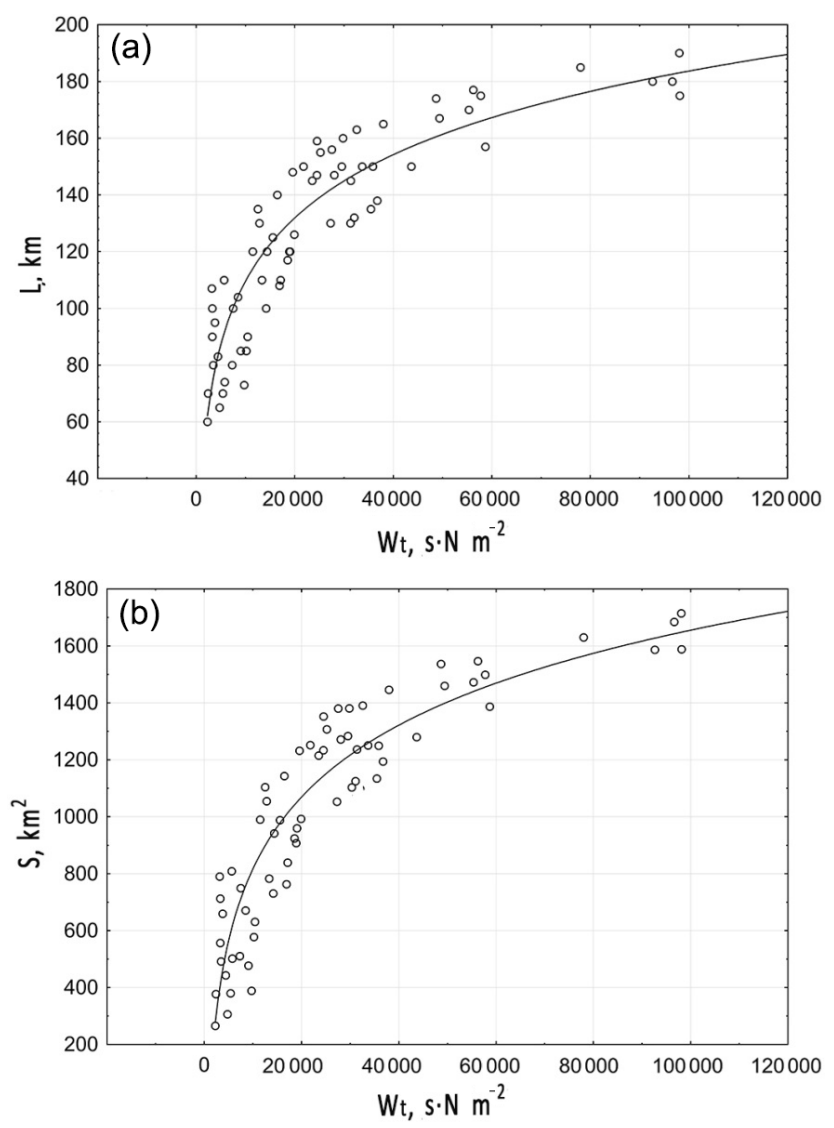

Figure 8. Dependence between the (a) alongshore extent of the AP and (b) the area of the AP, calculated from satellite data, on the $y$ axes, and the wind forcing index for the period of predominant north-easterly winds preceding the time of satellite observations, on the $x$ axes.

of 14-21 April 2003 caused the formation of the AP, which was followed by light and variable wind on 21-27 April 2003 and the formation of the BP detected in satellite imagery on 27 April 2003 (Fig. 10a). Formation of the BP detected in satellite imagery on 12 November 2015 was also preceded by, first, strong north-easterly wind (up to $10 \mathrm{~m} \mathrm{~s}^{-1}$ ) from 29 October to 1 November 2015 that caused the formation of the AP and, second, light and variable wind on 2-12 November 2015 (Fig. 10b).

A similar configuration of water exchange between the large Patos Lagoon and the Atlantic Ocean through a narrow strait was described by Castelao and Moller (2006). They revealed the formation of a reverse flow of saline ocean water to the lagoon after an outflow of brackish lagoon water induced by wind forcing. Our results are also supported by the in situ measurements of vertical current profiles performed reported by Ivanov et al. (2012). These measurements showed that moderate north-easterly winds observed on 26-27 September 2011 induced surface-to-bottom southward flow in the shallow northern part of the Kerch Strait. Light westerly wind observed on 28 September 2011 resulted
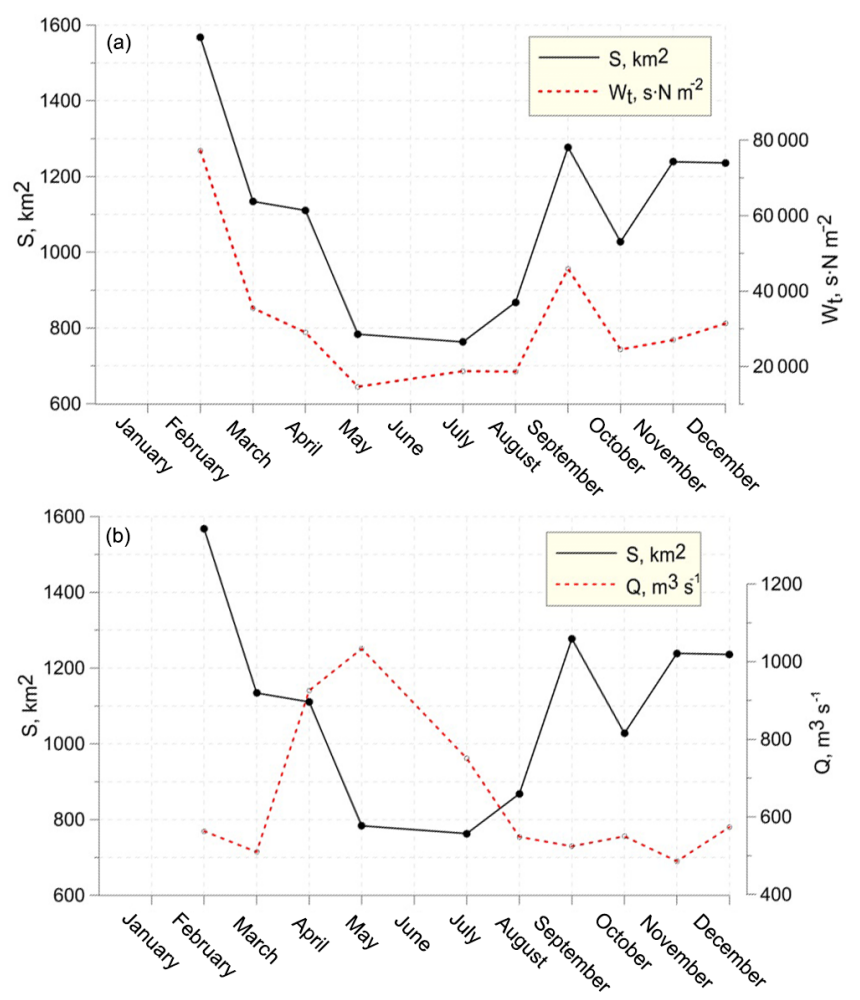

Figure 9. Dependence between (a) monthly averages of wind forcing index $W_{t}$ and (b) total discharge rate of the Don and Kuban rivers $Q$ on the one hand, and monthly averages of the area of the AP detected at optical satellite imagery, on the other hand.

in termination of the southward surface flow and the formation of a distinct surface-to-bottom northward flow.

\section{Discussion and conclusions}

In this work we studied water exchange between the Sea of Azov and the Black Sea through the Kerch Strait. We revealed that different physical mechanisms govern water transport in southward (from the Sea of Azov to the Black Sea, AI events) and northward (from the Black Sea to the Sea of Azov, BI events) directions. Analysis of satellite imagery, wind data, and numerical model outputs shows that water exchange in the Kerch Strait is governed by the windinduced barotropic pressure gradient. As a result, water flow through the shallow and narrow Kerch Strait is a one-way process for the majority of the time. Southward AI events are induced by moderate and strong north-easterly wind forcing. In this case, wind stress causes the transport of brackish waters from the shallow southern part of the Sea of Azov through the Kerch Strait, which results in the formation of the buoyant plume in the Black Sea. This surface-advected Azov Sea water plume (AP) is characterized by elevated concentrations of suspended sediments and chlorophyll $a$, and it can be detected in optical satellite imagery. The AP is spread- 
(a)

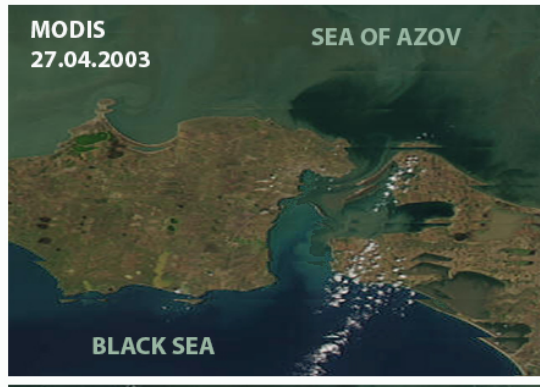

(b)

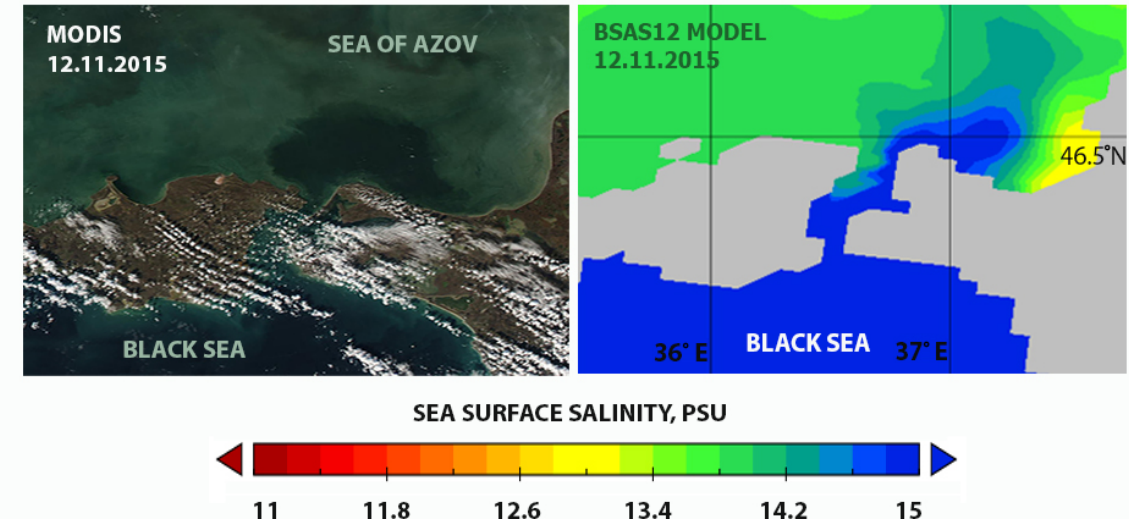

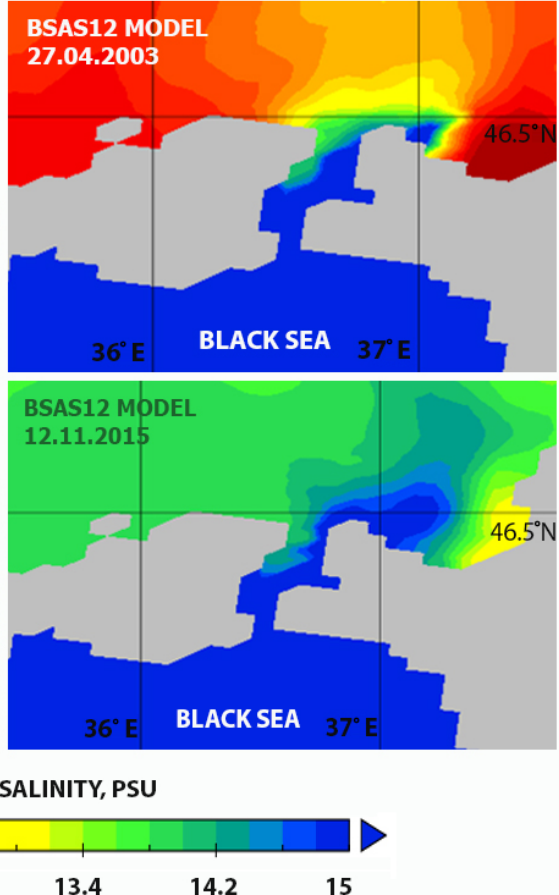

Figure 10. Formation of the BP after the wind relaxation on (a) 27 April 2003 and (b) 12 November 2015; retrieved from MODIS satellite data and confirmed by the BSAS12 model simulation.

ing off the Kerch Strait as a quasi-geostrophic coastal current along the south-eastern shore of the Crimean Peninsula; its area steadily increases during an AI event that lasts $1-5 \mathrm{~d}$. As a result, the AP occupies a large area in the north-eastern part of the Black Sea, up to $2000 \mathrm{~km}^{2}$. However, the AP dissipates $1-5 \mathrm{~d}$ after the end of an AI event. The short-term but regular process of formation and spreading of the AP at the north-eastern part of the Black Sea influences many local physical, biochemical, and geological processes, which were addressed in many previous studies.

The northward water transport in the Kerch Strait, oppositely, was registered after a relaxation of strong northeasterly winds that results in a reverse of the barotropic pressure gradient along the strait and triggers inflow from the Black Sea to the Sea of Azov. Thus, strong north-easterly wind plays a restricting role in this process because the intense wind-induced southward surface flow of waters from the Sea of Azov occupies the whole water column in the shallow northern part of the Kerch Strait. Analysis of satellite images did not show any direct dependence of northward water transport in the Kerch Strait on characteristics of local wind forcing. However, this feature can be caused by a relatively low number of detected BI events in satellite imagery. Future studies of the role of wind forcing in this process require more specific and detailed in situ measurements and/or numerical modelling.

We determined that wind forcing governs the direction and intensity of water transport in the Kerch Strait on an inter- annual timescale. River runoff to the Sea of Azov does not have any distinct influence on synoptic and seasonal variability in water exchange through the Kerch Strait; i.e. the signal of river discharge dissipates in the Sea of Azov and does not influence freshwater outflow from the estuary to the open sea. This feature is not typical for large river estuaries, e.g. the Patos Lagoon (Castelao and Moller, 2006) and the Amur Liman (Osadchiev, 2017). The relation between freshwater discharge to the river estuary and water exchange between the estuary and the open sea depends on two main factors, namely, the volume of inflowing river discharge and the spatial scales of an estuary. The volume of the Sea of Azov $\left(290 \mathrm{~km}^{3}\right)$ is 1 order of magnitude greater than the annual continental discharge to the sea $\left(20-54 \mathrm{~km}^{3}\right)$. River runoff during flooding periods only increases the level of the Sea of Azov by 6-7 cm compared to draught periods. As a result, the signal of seasonal discharge variability of the Don and Kuban rivers dissipates in the Sea of Azov and does not influence the intensity of water exchange through the Kerch Strait. In contrast, the volume of the Patos Lagoon $\left(50 \mathrm{~km}^{3}\right)$ is on the same order as the continental runoff volume $\left(75 \mathrm{~km}^{3}\right)$, which causes an increase in the lagoon level by $70-80 \mathrm{~cm}$ during wet periods. As a result, the stable seaward flow from the Patos Lagoon during the seasonal flood can only be reversed by very strong winds (Moller and Castaing, 1999). The volume of the Amur Liman $\left(20 \mathrm{~km}^{3}\right)$ is much less than the annual Amur discharge volume $\left(400 \mathrm{~km}^{3}\right)$. Therefore, water exchange between the Amur Liman and the open sea is domi- 
nated by the river regime during the majority of a year (Osadchiev, 2017).

Based on the quantitative relations between the spatial characteristics of the AP and the local wind forcing established in Sect. 4.2 we can reconstruct the dependence of the discharge rate from the Sea of Azov to the Black Sea through the Kerch Strait using the speed and duration of local wind forcing. First, we define "AI-favourable" wind conditions as a period of predominant north-easterly wind forcing with the wind forcing index $W_{t}$ exceeding $332.8 \mathrm{~s} \mathrm{~N} \mathrm{~m}^{-2}$. Second, using wind reanalysis data we identify periods of AI-favourable wind events. Finally, we calculate the areas of the AP formed during these events using the obtained relation between the wind forcing index and the area of the AP. The sum of these areas for all $\mathrm{AI}$ events occurring during a year $\left(S_{\mathrm{AP}}\right)$ is indicative of the total annual volume of water inflow from the Sea of Azov to the Black Sea through the Kerch Strait $\left(V_{\mathrm{AP}}\right)$. Simonov and Altman (1991) estimate the mean value of $V_{\mathrm{AP}}$ for the years $1963-1972$ as $64.3 \mathrm{~km}^{3}$, while we calculated that the mean value of $S_{\mathrm{AP}}$ for the years 1963-1972 is equal to $16571 \mathrm{~km}^{2}$. We assume that the mean depth of the AP $\left(H_{\mathrm{AP}}\right)$ does not substantially depend on its spatial scale and is mainly defined by the bathymetry of the Kerch Strait. Thus, we obtain $V_{\mathrm{AP}}=H_{\mathrm{AP}} S_{\mathrm{AP}}$, and the mean annual depth of the $\mathrm{AP}$ is $H_{\mathrm{AP}}=V_{\mathrm{AP}} / S_{\mathrm{AP}}=4 \mathrm{~m}$, which is consistent with depth of the Kerch Strait (Fig. 1). Finally, using the dependence of the plume area on the wind forcing index and the obtained estimate of the mean depth of the AP, we set the following equation for the water inflow volume during an $\mathrm{AI}$ event $(V)$ : $V=S \cdot H_{\mathrm{AP}}=-10150.8+3354.4 \cdot \lg \left(W_{t}\right)$.

Many numerical studies were focused on circulation, food webs, water quality, transport and fate of dissolved and suspended matter, and other processes in the Black Sea (e.g. Stanev, 1990; Oguz et al., 1995; Stanev and Staneva, 2000; Staneva et al., 2001; Enriquez et al., 2005; Korotenko et al., 2010; Korotenko, 2017; and Stanev et al., 2017). A majority of these studies did not simulate circulation in the Sea of Azov and the Kerch Strait but reproduced water exchange through the Kerch Strait as a boundary condition. However, these works generally applied mean annual or mean seasonal exchange values and neglected the fact that direction and discharge rates of the water transport through the Kerch Strait have strongly inhomogeneous temporal distributions and significant interannual variabilities. In particular, we are not aware of any relevant numerical parameterizations of water exchange through the Kerch Strait that reproduce its synoptic variability. Thus, the equations that define conditions of the formation of AI events and the dependence of the discharge rate during an AI event on speed and duration of north-easterly wind, which were obtained in the current study, promise to be useful for the numerical modelling of processes in the Black Sea. They can improve the existing parameterizations of the boundary conditions at the Kerch Strait and, therefore, increase the accuracy of numerical sim- ulations of physical, geological, and biochemical processes in the Black Sea.

Data availability. The Envisat MERIS satellite data were downloaded from the European Space Agency repository of the Envisat satellite data https://earth.esa.int/web/guest/-/ meris-full-resolution-full-swath-4215 (European Space Agency, 2019) (available after registration). The Terra MODIS and Aqua MODIS satellite data were downloaded from the National Aeronautics and Space Administration repository of LANCE-MODIS satellite data https://lance3.modaps.eosdis.nasa.gov (NASA, 2019). The river discharge and wind data were downloaded from the Federal Service for Hydrometeorology and Environmental Monitoring of Russia repositories http://gis.vodinfo.ru (Federal Service for Hydrometeorology and Environmental Monitoring of Russia repositories, 2019) (available after registration) and https://rp5.ru (Met Office, 2019). The NCEP/NCAR reanalysis data were downloaded from the National Oceanic and Atmospheric Administration website https://www.esrl.noaa.gov/psd/data/gridded/data.ncep. reanalysis.surface.html (NOAA National Center for Environmental Prediction, 2019).

Supplement. The supplement related to this article is available online at: https://doi.org/10.5194/os-16-15-2020-supplement.

Author contributions. IZ, AO, and RS wrote the main manuscript text; IZ and AO provided the satellite analysis; RS, BB, and JMC made the numerical simulation, and VB provided initial data for modelling; all authors prepared figures and reviewed the manuscript.

Competing interests. The authors declare that they have no conflict of interest.

Acknowledgements. The authors wish to thank the European Space Agency and the National Aeronautics and Space Administration for the provided satellite data, the Federal Service for Hydrometeorology and Environmental Monitoring of Russia for the provided river discharge data, and the National Oceanic and Atmospheric Administration for the provided atmospheric reanalysis data.

Financial support. This research has been supported by the Ministry of Science and Education of Russia, theme 0149-2019-0003 (collecting and processing of wind, river discharge, and satellite data), the Russian Foundation for Basic Research, research project 18-05-80049 (study of water exchange in the Kerch Strait), the Russian Science Foundation, research project 18-17-00156 (study of spreading of the Azov plume in the Black Sea), and the Russian Ministry of Science and Higher Education, research project 14.W03.31.0006 (developing of numerical modelling). Contribution to the BSAS12 modelling effort also came from the joint French-Russian cooperation programme PHC Kolmogorov, project 
number 38102RF (conducting of numerical experiments). The computations presented in this study were performed at the Centre Informatique National de l'Enseignement Supérieur (CINES) under the allocation made by GENCI, A0050100727.

Review statement. This paper was edited by Markus Meier and reviewed by Andrei Zatsepin and four anonymous referees.

\section{References}

Aleskerovà, A. A., Kubryakov, A. A., Goryachkin, Y. N., and Stanichny, S. V.: Propagation of waters from the Kerch Strait in the Black Sea, Phys. Oceanogr., 6, 47-57, https://doi.org/10.22449/1573-160X-2017-6-47-57, 2017.

Altiok, H., Sur, H. I., and Yuce, H.: Variation of the cold intermediate water in the Black Sea exit of the Strait of Istanbul (Bosphorus) and its transfer through the strait, Oceanologia, 54, 233-254, https://doi.org/10.5697/oc.54-2.233, 2012.

Andersen, S., Jakobsen, Fl., and Alpar, B.: The water level in the Bosphorus Strait and its dependence on atmospheric forcing, German Journal of Hydrography, 49, 466-475, https://doi.org/10.1007/BF02764341, 1997.

Barnier B., Madec G., Penduff T., Molines J.-M., Treguier A.-M., Sommer J. Le, Beckmann A., Biastoch A., Böning C., Dengg J., Derval C., Durand E., Gulev S., Remy E., Talandier C., Theetten S., Maltrud M., McClean J., and De Cuevas B.: Impact of partial steps and momentum advection schemes in a global ocean circulation model at eddy permitting resolution, Ocean Dynam., 56, 543-567, https://doi.org/10.1007/s10236-006-0082-1, 2006.

Belokopytov, V. N.: Retrospective analysis of the Black Sea thermohaline fields on the basis of empirical orthogonal functions, Phys. Oceanogr., 25, 380-389, https://doi.org/10.22449/1573160X-2018-5-380-389, 2018.

Beranger, K., Mortier, L., and Crepon, M.: Seasonal variability of water transport through the Straits of Gibraltar, Sicily and Corsica, derived from a high-resolution model of the Mediterranean circulation, Prog. Oceanogr., 66, 341-364, https://doi.org/10.1016/j.pocean.2004.07.013, 2005.

Castelao, R. M. and Moller Jr., O. O.: A modeling study of Patos lagoon (Brazil) flow response to idealized wind and river discharge: dynamical analysis, Braz. J. Oceanogr., 54, 1-17, https://doi.org/10.1590/S1679-87592006000100001, 2006.

Chepyzhenko, A. A., Chepyzhenko, A. I., and Kushnir, V. M.: Strait of Kerch water structure derived from the data of contact measurements and satellite imagery, Oceanology, 55, 47-55, https://doi.org/10.1134/S0001437015010038, 2015.

Cherkesov, L. V. and Shul'ga, T. Y.: Numerical Analysis of the Effect of Active Wind Speed and Direction on Circulation of Sea of Azov Water with and without Allowance for the Water Exchange through the Kerch Strait, Oceanology, 58, 19-27, https://doi.org/10.1134/S0001437018010022, 2018.

Dai, A., and Trenberth, K. E.: Estimates of freshwater discharge from continents: Latitudinal and seasonal variations, J. Hydrometeorol., 3, 660-687, https://doi.org/10.1175/15257541(2002)003<0660:EOFDFC >2.0.CO;2, 2002.

Danielson, S. L., Weingartner, T. W., Hedstrom, K., Aagaard, K., Woodgate, R.,Curchitser, E., and Stabeno, P.: Cou- pled wind-forced controls of the Bering-Chukchi shelf circulation and the Bering Strait through-flow: Ekman transport,continental shelf waves, and variations of the PacificArctic sea surface height gradient, Prog. Oceanogr., 125, 40-61, https://doi.org/10.1016/j.pocean.2014.04.006, 2014.

Doerffer, R. and Schiller, H.: The MERIS Case 2 Water Algorithm, Int. J. Remote Sensing, 28, 517-535, https://doi.org/10.1080/01431160600821127, 2007.

Enriquez, C. E., Shapiro, G. I., Souza, A. J., and Zatsepin, A. G.: Hydrodynamic modelling of mesoscale eddies in the Black Sea, Ocean Dynam., 55, 479-489, https://doi.org/10.1007/s10236005-0031-4, 2005.

European Space Agency: MERIS full resolution data repository, available at: https://earth.esa.int/web/guest/-/ meris-full-resolution-full-swath-4215, last access: 20 November 2019.

Falina, A., Sarafanov, A., Ozsoy, E., and Turuncoglu, U. U.: Observed basin-wide propagation of Mediterranean water in the Black Sea, J. Geophys. Res., 122, 3141-3151, https://doi.org/10.1002/2017JC012729, 2017.

Federal Service for Hydrometeorology and Environmental Monitoring of Russia repositories: Information system for water resources and water management of Russian river basins, available at: http://gis.vodinfo.ru, last access: 20 November 2019.

Ferrain, C., Bellafiore, D., Sannino, G., Bajo, M., and Umgiesser, G.: Tidal dynamics in the inter-connected Mediterranean, Marmara, Black and Azov seas, Prog. Oceanogr., 161, 102-115, https://doi.org/10.1016/j.pocean.2018.02.006, 2018.

Filippov, Y. G.: The impact of the Don River runoff on the water level in the Taganrog Bay, Russ. Meteorol. Hydrol., 40, 127-130, https://doi.org/10.3103/S1068373915020090, 2015.

Fomin, V. V., Polozok, A. A., and Fomina, I. N.: Simulation of the Azov Sea Water circulation subject to the river discharge, Phys. Oceanogr., 1, 15-26, https://doi.org/10.22449/1573-160X-2015$1-15-26,2015$

Fomin, V. V., Lazorenko, D. I., and Fomina, I. N.: Numerical modeling of water exchange through the Kerch Strait for various types of the atmospheric impact, Phys. Oceanogr., 4, 79-89, https://doi.org/10.22449/1573-160X-2017-4-79-89, 2017.

Fong, D. A. and Geyer, W. R.: The alongshore transport of freshwater in a surface-trapped river plume, J. Phys. Oceanogr., 32, 957-972, https://doi.org/10.1175/15200485(2002)032<0957:TATOFI>2.0.CO;2, 2002.

Fong, D. A., Geyer, W. R., and Signell, R. P.: The windforced response on a buoyant coastal current, Observations of the western Gulf of Maine plume, J. Mar. Syst., 12, 69-81, https://doi.org/10.1016/S0924-7963(96)00089-9, 1997.

Garmashov, A. V., Kubryakov, A. A., Shokurov, M. V., Stanichny, S. V., Toloknov, Y. N., and Korovushkin, A. I.: Comparing satellite and meteorological data on wind velocity over the Black Sea. Izvestiya, Atmospheric and Oceanic Physics, 52, 309-316, https://doi.org/10.1134/S000143381603004X, 2016.

Garrett, C.: The role of the Strait of Gibraltar in the evolution of Mediterranean water, properties and circulation, Bulletin de l'Institut Océanographique de Monaco, 17, 1-19, 1996

Garvine, R. W.: Estuary plumes and fronts in shelf waters: A layer model, J. Phys. Oceanogr., 17, 1877-1896, https://doi.org/10.1175/15200485(1987)017<1877:EPAFIS>2.0.CO;2, 1987. 
Ginzburg, A. I. Kostianoy, A. G., Krivosheya, V. G., Nezlin, N. P., Soloviev, D. M., Stanichny, S. V., and Yakubenko, V. G.: Mesoscale eddies and related processes in the northeastern Black Sea, J. Mar. Syst., 32, 71-90, https://doi.org/10.1016/S09247963(02)00030-1, 2002.

Goptarev, N. P., Simonov, A. I., Zatuchnaya, B. M., and Gershanovich, D. E.: Hydrometeorology and Hydrochemistry of the Soviet Seas, Vol. 5, The Sea of Azov., St. Petersburg, Gidrometeoizdat, 1991 (in Russian).

Gregg, M. C. and Ozsoy, E.: Flow, water mass changes, and hydraulics in the Bosphorus, J. Geophys. Res.-Oceans, 107, 2-1-223, https://doi.org/10.1029/2000JC000485, 2002.

Gregg, M. C., Ozsoy, E., and Latif, M. A.: Quasi-steady exchange flow in the Bosphorus, Geophys. Res. Lett., 26, 83-86, https://doi.org/10.1029/1998GL900260, 1999.

Hallock, Z. R. and Marmorino, G. O.: Observations of the response of a buoyant estuarine plume to upwelling favourable winds, J. Geophys. Res., 107, 3066, https://doi.org/10.1029/2000JC000698, 2002.

Horner-Devine, A. R., Hetland, R. D., and MacDonald, D. G.: Mixing and transport in coastal river plumes, Annu. Rev. Fluid Mech., 47, 569-594, https://doi.org/10.1146/annurevfluid-010313-141408, 2015.

Ilyin, Yu. P., Fomin, V. V., D'yakov, N. N., and Gorbach, S. B.: Hydrometeorological Conditions of the Ukraine Seas. Vol. 1. The Azov Sea, Sevastopol, ECOSI-Gidrofizika, 2009 (in Russian).

Ivanov, V. A. and Belokopytov, V. N.: Oceanography of the Black Sea, Sevastopol, ECOSI-Gidrofizika, 2013.

Ivanov, V. A., Cherkesov, L. V., and Shul'ga, T. Y.: Extreme deviations of the sea level and the velocities of currents induced by constant winds in the Azov Sea, Phys. Oceanogr., 21, 98-105, https://doi.org/10.1007/s11110-011-9107-5, 2011.

Ivanov, V. A., Morozov, A. N., Kushnir, V. M., Shutov, S. A., and Zima, V. V.: Currents in the Kerch Strait, adcp-observations, September, 2011, Ecological safety of coastal and shelf zones and complex usage of shelf resources, 26-1, 170-178, 2012 (in Russian).

Izhitskiy, A. S. and Zavialov, P. O.: Hydrophysical state of the Gulf of Feodosia in May 2015, Oceanology, 57, 485-491, https://doi.org/10.1134/S0001437017040105, 2017.

Jakobsen, F. and Trébuchet, C.: Observations of the transport through the Belt Sea and an investigation of the momentum balance, Cont. Shelf Res., 20, 293-311, https://doi.org/10.1016/S0278-4343(99)00073-4, 2000.

Jaoshvili, S.: The rivers of the Black Sea, European Environmental Agency, edited by: Chomeriki, I., Gigineishvili, G., and Kordzadze, A., Technical Report No. 71, 2002.

Kolyuchkina, G. A., Belyaev, V. A., Spiridonov, V. A., and Simakova, U. V.: Long-term effects of Kerch Strait residual oil-spill: hydrocarbon concentration in bottom sediments and biomarkers in Mytilus galloprovincialis (Lamarck, 1819), Turk. J. Fish. Aquat. Sc., 12, 461-469, https://doi.org/10.4194/13032712-v12_2_37, 2012.

Korotaev, G., Oguz, T., Nikiforov, A., and Koblinsky, C.: Seasonal, interannual, and mesoscale variability of the Black Sea upper layer circulation derived from altimeter data, J. Geophys. Res., 108, 3122, https://doi.org/10.1029/2002JC001508, 2003.

Korotenko, K. A.: Modeling processes of the protrusion of near-coastal anticyclonic eddies through the Rim
Current in the Black Sea, Oceanology, 57, 394-401, https://doi.org/10.1134/S0001437017020114, 2017.

Korotenko, K. A., Malcolm, J. B, and David, E. D.: High-resolution numerical model for predicting the transport and dispersal of oil spilled in the Black Sea, Terr. Atmos. Oceanic Sci., 21, 123-136, https://doi.org/10.3319/TAO.2009.04.24.01(IWNOP), 2010.

Kourafalou, V. H., Lee, T. N., Oey, L., and Wang, J.: The fate of river discharge on the continental shelf: 2.Transport of coastal lowsalinity waters under realistic wind and tidal forcing, J. Geophys. Res., 101, 3435-3456, https://doi.org/10.1029/95JC03025, 1996.

Kubryakov, A. A., Aleskerova A. A., Goryachkin, Yu. N., Stanichny, S. V., Latushkin, A. A., and Fedirko A. V.: Propagation of the Azov Sea waters in the Black sea under impact of variable winds, geostrophic currents and exchange in the Kerch Strait, Prog. Oceanogr., 176, 102119, https://doi.org/10.1016/j.pocean.2019.05.011, 2019.

Large, W. G. and Yeager, S. G. Diurnal to decadal global forcing for ocean and sea-ice models: the data sets and flux climatologies, NCAR Technical Note, NCAR/TN-460+STR, National Center for Atmospheric Research, 2004.

Lomakin, P. D., Panov, D. B., and Spiridonova, E. O.: Specific features of the inter-annual and seasonal variations of hydrometeorological conditions in the region of Kerch Strait for the last two decades, Phys. Oceanogr., 20, 109-121, https://doi.org/10.1007/s11110-010-9071-5, 2010.

Lomakin, P. D., Chepyzhenko, A. I., and Chepyzhenko, A. A.: Field of the colored dissolved organic matter concentration in the Sea of Azov and the Kerch Strait waters based on optical observations, Phys. Oceanogr., 5, 71-83, https://doi.org/10.22449/1573160X-2016-5-71-83, 2016.

Lomakin, P. D., Chepyzhenko, A. I., and Chepyzhenko, A. A.: The total suspended matter concentration field in the Kerch strait based on optical observations, Phys. Oceanogr., 6, 58-69, https://doi.org/10.22449/1573-160X-2017-6-58-69, 2017.

Madec, G. and the NEMO team: NEMO ocean engine. Note du Pôle de modélisation, Institut Pierre-Simon Laplace (IPSL), France, 27, 1288-1619, 2016.

Marques, W. C., Fernandes, E. H., Monteiro, I. O., and Moller, O. O.: Numerical modeling of the Patos Lagoon coastal plume, Brazil, Cont. Shelf Res., 29, 556-571, https://doi.org/10.1016/j.csr.2008.09.022, 2009.

Matthäus, W. and Lass H. U.: The Recent Salt Inflow into the Baltic Sea, J. Phys. Oceanogr., 25, 280-288, 1995.

Medvedev, I. P.: Tides in the Black Sea: observations and numerical modelling, Pure Appl. Geophys., 175, 1951-1969, https://doi.org/10.1007/s00024-018-1878-x, 2018.

Medvedev, I. P., Rabinovich, A. B., and Kulikov, E. A.: Tides in three enclosed basins: the Baltic, Black, and Caspian seas, Front Mar. Sci., 3, 46, https://doi.org/10.3389/fmars.2016.00046, 2016.

Met Office: Weather forecast website in Russia, available at: http: //rp5.ru, last access: 20 November 2019.

Miranda, L. B., Andutta, F. P., Kjerfve, B., and de Castro Filho, B. M.: Fundamentals of estuarine physical oceanography, 8, Springer, Singapore, https://doi.org/10.1007/978-981-10-30413, 2017.

Moller, O. O. and Castaing, P.: Hydrographical Characteristics of the Estuarine Area of Patos Lagoon ( $30^{\circ} \mathrm{S}$, Brazil), in: Estuaries of South America. Their Geomorphology and Dynamics, edited 
by: Perillo, G. M. E., Piccolo, M. C., and Quivira, M. P., Berlin, Springer-Verlag, 83-100, 1999.

NASA: National Aeronautics and Space Administration repository of LANCE-MODIS satellite data, available at: https://lance3. modaps.eosdis.nasa.gov, last access: 20 November 2019.

NOAA National Center for Environmental Prediction: NCEP/NCAR Reanalysis 1, availale at: https://www.esrl. noaa.gov/psd/data/gridded/data.ncep.reanalysis.surface.html, last access: 20 November 2019.

Officer, C. B.: Physical Oceanography of Estuaries (and associated coastal waters), Wiley, New York, https://doi.org/10.4319/lo.1977.22.5.0975, 1976.

Oguz, T., La Violette, P. E., and Unluata, U.: The upper layer circulation of the Black Sea: its variability as inferred from hydrographic and satellite observations, J. Geophys. Res.-Oceans, 97, 12569-12584, https://doi.org/10.1029/92jc00812, 1992.

Oguz, T., Latun, V. S., Latif, M. A., Vladimirov, V. V., Sur, H. I., Markov, A. A., Ozsoy, E., Kotovshchikov B. B., Eremeev, V. V., and Unluata, U.: Circulation in the surface and intermediate layers of the Black Sea, Deep-Sea Res. Pt. I, 40, 1597-1612, https://doi.org/10.1016/0967-0637(93)90018-X, 1993.

Oguz, T., Malanotte-Rizzoli, P., and Aubrey, D.: Wind and thermohaline circulation of the Black Sea driven by yearly mean climatological forcing, J. Geophys. Res.-Oceans, 100, 6845-6863, https://doi.org/10.1029/95JC00022, 1995.

Osadchiev, A. and Korshenko, E.: Small river plumes off the northeastern coast of the Black Sea under average climatic and flooding discharge conditions, Ocean Sci., 13, 465-482, https://doi.org/10.5194/os-13-465-2017, 2017.

Osadchiev, A. A.: A method for quantifying freshwater discharge rates from satellite observations and Lagrangian numerical modeling of river plumes, Environ. Res. Lett., 10, 085009, https://doi.org/10.1088/1748-9326/10/8/085009, 2015.

Osadchiev, A. A.: Spreading of the Amur river plume in the Amur Liman, the Sakhalin Gulf, and the Strait of Tartary, Oceanology, 57, 376-382, https://doi.org/10.1134/S0001437017020151, 2017.

Osadchiev, A. A. and Sedakov, R. O.: Spreading dynamics of small river plumes off the northeastern coast of the Black Sea observed by Landsat 8 and Sentinel-2, Remote Sens. Environ., 221, 522533, https://doi.org/10.1016/j.rse.2018.11.043, 2019.

Osadchiev, A. A. and Zavialov, P. O.: Lagrangian model for surface-advected river plume, Cont. Shelf Res., 58, 96-106, https://doi.org/10.1016/j.csr.2013.03.010, 2013.

Osadchiev, A. A., Korotenko, K. A., Zavialov, P. O., Chiang, W.-S., and Liu, C.-C.: Transport and bottom accumulation of fine river sediments under typhoon conditions and associated submarine landslides: case study of the Peinan River, Taiwan, Nat. Hazards Earth Syst. Sci., 16, 41-54, https://doi.org/10.5194/nhess-16-412016, 2016.

Osadchiev, A. A., Izhitskiy, A. S., Zavialov, P. O., Kremenetskiy, V. V., Polukhin, A. A., Pelevin, V. V., and Toktamysova, Z. M.: Structure of the buoyant plume formed by $\mathrm{Ob}$ and Yenisei river discharge in the southern part of the Kara Sea during summer and autumn, J. Geophys. Res.-Oceans, 122, 5916-5935, https://doi.org/10.1002/2016JC012603, 2017.

Ostrander, C. E., McManus, M. A., Decarlo, E. H., and Mackenzie, F. T.: Temporal and spatial variability of freshwater plumes in a semi-enclosed estuarine-bay system, Estuar. Coast., 31, 192203, https://doi.org/10.1007/s12237-007-9001-z, 2008.

Ross, D. A.: The Black Sea and the Sea of Azov, in: The Ocean Basins and Margins, edited by: Nairn, A. E. M., Kanes, W. H., and Stehli, F. G.: 4A, 445-481, Springer, Boston, MA, https://doi.org/10.1007/978-1-4684-3036-3_11, 1977.

Sannino, G., Bargagli, A., and Artale, V.: Numerical modelling of the mean exchange through the Strait of Gibraltar, J. Geophys. Res., 107, 1-24, https://doi.org/10.1029/2001JC000929, 2002.

Sapozhnikov, V. V., Kumantsov, M. I., Agatova, A. I., Arzhanova, N. V., Lapina, N. M., Roi, V. I., Stolyarskii, S. I., Bondarenko, L. G., Panov, B. N., Grishin, A. N., and Zhugailo, S. V.: Complex investigations of the Kerch Strait, Oceanology, 51, 896, https://doi.org/10.1134/S0001437011050146, 2011.

Sayin, E. and Krauß, W.: A numerical study of the water exchange through the Danish Straits, Tellus A, 48, 324-341, https://doi.org/10.1034/j.1600-0870.1996.t01-1-00009.x, 1996.

Sellschoppa, J., Arneborgb, L., Knolla, M., Fiekasa, V., Gerdesa, F., Burchardc, H., Lass, H. U., Mohrholz, V., and Umlauf, L.: Direct observations of a medium-intensity inflow into the Baltic Sea, Cont. Shelf Res., 26, 2393-2414, https://doi.org/10.1016/j.csr.2006.07.004, 2006.

She, J., Berg, P., and Berg, J.: Bathymetry impacts on water exchange modelling through the Danish Straits, J. Mar. Syst., 65, 450-459, https://doi.org/10.1016/j.jmarsys.2006.01.017, 2007.

Sheldon, J. E. and Alber, M.: A comparison of residence time calculations using simple compartment models of the Altamaha River estuary, Georgia, Estuaries, 25, 1304-1317, https://doi.org/10.1007/BF02692226, 2002.

Simonov, A. I. and Altman, E. N.: Hydrometeorology and Hydrochemistry of the USSR seas. Vol. 4. The Black Sea, St. Petersburg, Gidrometeoizdat, 1991 (in Russian).

Soto-Navarro, J., Somot, S., Sevault, F., Beuvier, J., CriadoAldeanueva, F., Garca-Lafuente, J., and Béranger, K.: Evaluation of regional ocean circulation models for the Mediterranean Sea at the Strait of Gibraltar: volume transport and thermohaline properties of the outflow, Clim. Dynam., 44, 1277-1292, https://doi.org/10.1007/s00382-014-2179-4, 2015.

Sozer, A. and Ozsoy, E.: Modeling of the Bosphorus exchange flow dynamics, Ocean Dynam., 67, 321-343, https://doi.org/10.1007/s10236-016-1026-z, 2017.

Stanev, E. V.: On the mechanisms of the Black Sea circulation, Earth-Sci. Rev., 28, 285-319, https://doi.org/10.1016/00128252(90)90052-W, 1990.

Stanev, E. V. and Staneva, J. V.: The impact of the baroclinic eddies and basin oscillations on the transitions between different quasistable states of the Black Sea circulation, J. Mar. Syst., 24, 3-26, https://doi.org/10.1016/S0924-7963(99)00076-7, 2000.

Stanev, E. V., Roussenov, V. M., Rachev, N. H., and Staneva, J. V.: Sea response to atmospheric variability. Model study for the Black Sea, J. Mar. Syst., 6, 241-267, https://doi.org/10.1016/0924-7963(94)00026-8, 1995.

Stanev, E. V., Grashorn, S., and Zhang, Y. J.: Cascading ocean basins: numerical simulations of the circulation and interbasin exchange in the Azov-Black-MarmaraMediterranean Seas system, Ocean Dynam., 67, 1003-1025, https://doi.org/10.1007/s10236-017-1071-2, 2017.

Staneva, J. V., Dietrich, D. E., Stanev, E. V., and Bowman, M. J.: Rim Current and coastal eddy mechanisms in an eddy-resolving 
Black Sea general circulation model, J. Mar. Syst., 31, 137-157, https://doi.org/10.1016/S0924-7963(01)00050-1, 2001.

Titov, V. B.: Characteristics of the Main Black Sea Current and nearshore anticyclonic eddies in the Russian sector of the Black Sea, Oceanology, 42, 637-645, 2002.

Wang, C. F., Hsu, M. H., and Kuo, A. Y.: Residence time of the Danshuei River estuary, Taiwan, Estuar. Coast. Shelf Sci., 60, 381-393, https://doi.org/10.1016/j.ecss.2004.01.013, 2004.

Washburn, L., McClure, K. A., Jones, B. H., and Bay, S. M.: Spatial scales and evolution of stormwater plumes in Santa Monica Bay, Mar. Environ. Res., 56, 103-125, https://doi.org/10.1016/S01411136(02)00327-6, 2003.

Woodgate, R. A., Aagaard, K., and Weingartner, T. J.: Interannual changes in the Bering Strait fluxes of volume, heat and freshwater between 1991 and 2004, Geophys. Res. Lett., 33, L15609, https://doi.org/10.1029/2006GL026931, 2006.

Woodgate, R. A., Weingartner, T., and Lindsay, R.: The 2007 Bering Strait oceanic heat flux and anomalous Arctic sea-ice retreat, Geophys. Res. Lett., 37, L01602, https://doi.org/10.1029/2009GL041621, 2010.

Woodgate, R. A., Weingartner, T. J., and Lindsay, R.: Observed increases in Bering Strait oceanic fluxes from the Pacific to the Arctic from 2001 to 2011 and their impacts on the Arctic Ocean water column, Geophys. Res. Lett., 39, L24603, https://doi.org/10.1029/2012GL054092, 2012.
Xia, M., Xie, L., and Pietrafesa, L. J.: Modeling of the Cape Fear River estuary plume, Estuar. Coast., 30, 698-709, https://doi.org/10.1007/BF02841966, 2007.

Yankovsky, A. E. and Chapman, D. C.: A simple theory for the fate of buoyant coastal discharges, J. Phys. Oceanogr., 27, 1386-1401, https://doi.org/10.1175/15200485(1997)027<1386:ASTFTF>2.0.CO;2, 1997.

Yuce, H.: Mediterranean water in the Strait of Istanbul (Bosphorus) and the Black Sea exit, Estuar. Coast. Shelf Sci., 43, 597-616, https://doi.org/10.1006/ecss.1996.0090, 1996.

Zatsepin, A. G., Ginzburg, A. I., Kostianoy, A. G., Kremenitskiy, V. V., Krivosheya, V. G., Stanichny, S. V., and Poulain, P.-M.: Observations of Black Sea mesoscale eddies and associated horizontal mixing, J. Geophys. Res., 108, 3246, https://doi.org/10.1029/2002JC001390, 2003.

Zavialov, P. O., Izhitskiy, A. S., and Sedakov, R. O.: Sea of Azov waters in the Black Sea: Do they enhance wind-driven flows on the shelf?, in: The Ocean in Motion, edited by: Velarde, M., Tarakanov, R., and Marchenko, A., Springer Oceanography, Springer, Cham, 461-474, https://doi.org/10.1007/978-3319-71934-4_28, 2018. 